会長講演

\title{
Billroth 教授の教育
}

\author{
熊本大学第 2 外科 \\ 小川道雄
}

Theodor Billroth 教授 (1829〜1894) の門下からは数多くの外科学の指導者が輩出した . Billroth が遺した書簡，発表した論文や書籍の中から，彼が外科医を育てるためにどのような教育を行ってい たか , 彼か理想の教育者についてどのような考えをもっていたか，について推察した .

\section{1.はじめに}

T heodor Billroth 教授は胃癌切除に初めて成功した のみならず,多くの悪性腫瘍の摘出にも成功している. 同時に作曲家 Brahms との交流，家族への深い愛情も よく知られている.しかし忘れてならないことに , 数 多くの外科学の指導者を育てたことがある．

Billroth 教授については新潟大学の堺教授が, 杂隹誌 「外科」に「T heodor Billroth 教授の生涯」として，す ぐれた伝記を4回にわたって連載された ${ }^{11}$.今回は Billroth 教授の教育を中心に，堺教授が触れておられ ないところをまとめてみた .

\section{Art と Science}

1867年10月，Billroth はウィーン大学第 2 外科教授 に就任し，記念講演を行った .このときBillrothは38 歳であった . 対象は教室員, 学生, 弚れにウィーン医 師会員である .

$\ulcorner\ldots .$. 諸君は医学の研修に必要であるものと、除くべき ものについて , 私の判断を信じなければならない . 過去において理論と言われてきたものは，私の講義 では実地に応用するための病理解剖学と生理学とし て講義される.私の指導を信頼してほしい! 私を信 じてほしい! 私は理論から実践へと続く道を知って いる. 弚の道を何百回も歩いている，…諸君が忠 実に私の道を歩むなら，弚れには大きな努力を必要 とするかもしれないが, ウィーン大学外科は炎の炎 を保つことができるだろう.諸君，もちろん諸君は 働かなければならない . 教室の将来は教室員ひとり ひとりの働きにかかっている，国家の将来が市民ひ

※第55回日消外会総会

$<2000$ 年12月19日受理 $>$ 別刷請求先 : 小川 道雄 T 860-8556 熊本市本荘2-2-1 熊本大学医学部第 2 外科
とりひとりの働きにかかっているように」(1867年) と高らかに宣言している ここでいう理論と実践とは， 外科学としてのWissenschaft と, 外科のもつ kunstlerische Seite に置き換えることができる .

Billroth は常に外科の kunstlerische Seite，技術的な 側面 (ここでは art と訳す) を外科の Wissenschaft (こ こでは science と訳す)と結びつけようとしていた .乥 して,

「外科の art を science に結びつけることが，われわ れの時代の目標である」(1876年)

と繰り返してきた .すでに Langenbeck 外科在籍中の 手紙に，

「過去と現在における art と science に精通した者 にのみ，弚の発展を推進する資格がある」(1858年) と述べている.また，Zurich 大学教授時代にも

「理論と実践, science と art の間に適切な関係があ れば，乥れは常に学生を刺激し続ける．孤立した理 論が，しばしば不毛の推論に終わるように，孤立し た技術は，決まりきった機械にしかならない．…... (1860年)

とし , art のみにとどまれば,外科は大工仕事でしかな いことを説いている．

当然のことながら，このような新しい外科学は門下 生を除いては, 受け入れられなかった . 後年 Mikulicz は Billroth の追悼文の中で光のことに触れている．

「最初の頃，先生は誤って評価されていた.多分乥れ は嫉妬心からだろう . 人々は先生の本当の能力を認 めようとしなかった .なるほど彼は優れた学者では あるが，実地外科では全くの素人だ，という意見だっ た．しかし，われわれ門下生は，このような噂を一 顧だにしなかった . われわれにとっては先生は教授 の理想であり, 先生のためなら, 最初の学期から火 


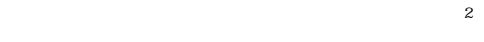

\section{3. 指導体制}

Billroth はすでにZürich 時代から Oberarzt が指導 する体制をつくっていた .これは後に Halstedによっ てアメリカに持ち込まれ, resident sy stem として完成 される.Billroth は現在の外科修練システムの考案者 である

その頃の指導体制については, Mikulicz が次のよう に Billroth の追悼文に述べている .

「1875年の復活祭のとき，幸運にも私は Billroth 外科 教室に副手(O perationszügling)として採用された 。 教室は厳格な，ほとんど軍隊のような組織だった . 2人の助手，8人の志願医(みな学位をもっていた)が 臨床を分担していた . 弚れ以下の者は，例外なく助 手に指導されていた . 臨床診療がある段階まで達し てはじめて，先生と少しずつ個人的に接することが できるようになった」

さらに，次のような Mikulicz の記載もある .

「助手になるまでの 3 年の間, 副手 (Operationszui gling ) という，いわば้の下の医師として働いた . 独立した助手の地位につくまでに，このように長く 待たねばならなかったことについては, 後悔してい ない . 私の考えでは, Billroth 外科の力は, 徒弟 , 職 人 , 親方というギルドのような制度にあった . われ われの時代の多くの外科医がもつ, メスが自分の唯 一の手段であるというような一方的な見方を，門下 生が早い時期から身に付けてしまわないように，と 先生は考えておられたさ2

教室員への指示について Mikulicz は， $\ulcorner$ 先生の古参の助手への指示は，暗黙のうちに伝えら れた . 先生は彼らを信用しておられたので，ほとん ど制限のない独立か許されていた．また，彼らの助 言や提案を喜んで検討された，乥して，ご自分の考 えより良いと判断されれば，彼らの考えを受け入れ られた .このためすぐに親密な関係が生まれ，光し て後になってほとんどの場合，弚れが永遠の友情に まで発展していった」

と言っている。

Billroth は門下生の間違いを強く叱責することはな かったようである .Züirich 時代に

「誰でも間違いをおかす，豊富な経験のある者でさえ も．しかし，経験のある者が間違いをおかす頻度は 低い」(1865年)

と書いている .

\section{4. 手術と手術適応}

Billroth は胃癌はじめ, 喉頭癌, 甲状腺癌, 頸部食道 癌など多くの悪性腫瘍の摘除に成功している。

Billroth の手術について Mikulicz は，

$\ulcorner$ (手術のとき) 先生は手を本当に優雅に動かされた ので，お元気な頃は，先生が手術をなさるのを見る のは, 喜びであった」

と述べている．乥してまた，

「先生はわれわれ若い医局員に，手術でメスをどのよ うに手早く使うか，特別の注意を与えられた .この とき，先生はいつも Langenbeck の名前を挙げられ た .先生の心の中では,Langenbeck は理想的な外科 医だった」

と, Billroth が 6 年余の間指導を受けた Langenbeck の名前を挙げたことを Mikulicz は記している .

Billroth は手術の術者とすることには慎重であっ た。

「多くの手術を見学することによってのみ，手術に成 功することができるようになる．もし見学を行わな いなら，多くの悲劇的な手術からはじめることにな

り，患者は被害を被る」(1866年)

に弚れが出ている.Mikulicz も，

「われわれが自分で手術をすることを許可されるの は, かなり年数が経ってからであった . 产れも先生 か助手の一人の指導がなければ, 手術は許されな かった」

と述べている。

また , 手術適応についての Billroth の考えは 「成功のチャンスがあるときのみ，外科的処置を行う ことが許される.チャンスがないのに手術をする者 は,美しい art と science を冒涜するものである.乥 して外科は一般大衆やわれわれの同僚の医師達に疑 いの目でみられるようになるだろう」(1877年)

と，慎重であった .

\section{5 . 研究と論文の指導}

研究について， Mikulicz は次のように述べている． 「先生は早いうちから われわれが光れ独立した 課題をもつことをすすめられた .すべての者に , 出 来の良くない者でさえも，論文を書く機会を与えら れた，弚のとき，直接の細かな指示はほとんどなかっ た . 能力のある者には, 弚れで十分だった」) Billroth は研究においては， 「すべての観察結果は，新しい概念と結びつく，乥の 概念は新しい観察を導く」(1865年) 
と，弚れが進歩につながることを説き，研究をするこ とをすすめている .

Mikulicz は追悼文の中に，

「論文を提出すると，先生は光の評価を書いて下さっ た . 私の知る限り，小さな追加や削除は別として， 門下生の論文は，ほんの少ししか変えられなかった . しかし，光の評価には最大限の注意を払っておられ た .まず最初に，良い点を誉め，乥の論文をどのよ うにしたらより良くできるかについて，秪やかなし かも有益な助言を与えられた

と記している。

Mikulicz の頭部の der moid の研究論文について， Billroth の助言は次のようなものであった .

「教えるだけでなく書くことによっても学ぶー二れ からはもっと簡潔にしなさい. 弚うすればより効果 が上がるし，印象的になる．読者が行間から，自分 の考えを見つけられるという利点もある」(1875年) 論文は Billroth 自身が自分で書く方が余程早いはず であるが,光れをせず,Billroth は論文の指導に時間を かけている。

「今，1869年の年報に取りかかった .今年も教室員の 行ったいくつかの優れた仕事が論文になるだろう. 原稿の指導や訂正にはとても時間がかる . 現在の 私の地位では，自分で論文を書かないこと，光れに ついて若い人を教育することが , 私の義務と考えて いる」(1869年)

という手紙がある .

6. Durch Klarheit zur Wahrheit

Billroth は Zurich 時代から研究において統計的解析 を重視していた．また，治療成績をごまかすことのな いよう，すべての結果を示すように教育していた .

「自分の治療経験を数字で示すことのできない者は 「山師」である．…真理に達するためには明瞭に示さ ねばならない .どのような方法でどこが進歩したか を明らかにせよ . 失敗を認めるのを躊躇してはなら ない」(1867年)

Durch Klarheit zur W ahrheit は教室訓となってい る.

そのため，後世のものは Billroth 外科の年報から，乥 の治療成績を算出することができる．例えば防腐法の 導入前後のウィーン大学第 2 外科における開腹手術の 死亡率は，54.3\%から30.1\%まで低下している．また， ウィーン大学 Billroth 外科の開腹手術における手術術 式別平均死亡率では, 胃の手術の死亡率は49.5\%であ
り，さらに, 試験開腹でも平均 $33.6 \%$ が死亡したことが 分かる.

\section{7 . 学生教育}

Billroth の学生教育に関する考えは，

「恵まれた才能でさえも 型にはまった形式的な教育 の中では, やがて硬直したものになってしまうだろ う $(\text { 1876年 })^{3)}$

であった 。

Billroth の考えは，手を取って教えるのではなく，自 発的な学習の意欲こ乥が重要だ，というものである．

「(学生は) 講義て教師が言ったことを，乥れほど覚 えてはいないものだが , 教師の助けによって, 自分 が自然の秘密を見抜いて，真理を理解する能力を得 つつあるということを感じることは，すべての思慮 深い学生にとって計り知れない魅力なのである」 (1876年) $)^{3)}$

と述べている．

講義の内容は学生には難しかったようである . 追悼 文でMikuliczは，

$\ulcorner$ (講義は) 学生, 中でも初年度の学生が聞き慣れて いるような，通り一辺のものではなかった . 残念な がら多くの学生が求めているような，筆記すれば光 のまま試験準備のための「まとめ」になるような講 義ではなかった . 先生は狭い意味の研究者だけでは なく，すべての医師に必要となる観察や検索の方法 を示されたっ

と述べている．しかし，講義では理解させるようにい ろいろと土夫もしていた .

「先生の思考の筋道を知らない者は 誰も先生の講義 を理解することはできなかった．しかし，先生は出 来の悪い学生のために, 昔からの方法で教えようと されることも多かった . ただ先生は熱中されると， すぐにあの独特の，魅力的な講義に戻ってしまわれ た . 先生は文字通りの学校教師という才能は, 持っ ておられなかった」

とMikulicz は控え目に言っている .

乥れでも学生の出席はよくならなかった。

「私は一般外科の講義を，毎学期ごとに工夫している のだが，出席は少なくなるばかりだ . そこでとうと う諦めて，第二の試みをした．手術の供覧を階段教 室で行った.講義には 7 人の出席だったのが， 500 人も集まり，光の重さで教室が壤れ弚うになった」 (1874年) と嘆いている . 
この当時, ウィーン大学の学生数は年平均1,379名 で，しかも光れは増え続けていた．弚れに対して他の 医学校では34名から88名,プラハでさえも年間388名で あった．医学部長のRokitansky は，学生を Krakow や Budapest 八転校させるべく工夫を凝らしたが，成 功していない

学生の試験について, Mikuliczは，

「先生は試験のときはいつも穏やかで寛大な試験官 だった．外科的な視点から見て正しければ，先生と 正反対の答えであっても合格させた」2

と記している。

8. Billroth 門下と Langenbeck 門下

Billroth の門下からは , Czerny , Mikulicz , Gussenbauer, Eiselsberg , Wölfler, Gersuny , Frankel な ど数多くの外科教授や指導医が輩出している.さらに， Billroth が教育したこれらの教授からも，さらに多く の指導者が出ている.

Billroth は Langenbeck の指導を受けた . Langenbeck は文字通り当時のドイツ外科学界の帝王であっ た .しかし皆，Langenbeck の門下と言わずに Billroth の門下と言う .この理由としては，もちろん Billroth が麻酔法，防腐法という関連領域の進歩を得て，多く の手術に成功したことがあろう．しかし理由は关れだ けではないように思う．

Berlin 大学でLangenbeck の講義を聴き，手術を見 学した1852年に，Billroth は Langenbeck について友 人宛の多くの書簡を残している . Langenbeck が再発 乳癌患者に手術で, 術前に診察を十分にしなかったた め, 癌が切開部の真下から大きく広がっており , 患者 が死亡したのを目撃したとき，次のように書き送って いる .

「Langenbeck は思慮が浅く，うわべだけで, 取るに 足らない．...彼はこの患者を簡単に診察しただけ だった．‥癌は胸膜にまで達していた．もし彼が患 者をよく診察していたら，こんなことは起こらな かった」(1852年)

また，こんな感想もある。

$\ulcorner$ Langenbeck は全くとんでもない間違いをおかす． ことに関節患者について．．とどれだけ多くBaum 先生の正確さと基礎的知識の豊富さを考えたこと か」(1852年)

と Langenbeck を恩師 Baum と比較している . 外科医 は臨床診療とともに，当時の基礎科学，病理学の深い 知識が必要であると，すでに若い Billroth は鋭い観察
をしている。

次のような手紙もある .

「今になってはじめて ,Baum 先生の講義の価值を評 価したと認めざるを得ない .Langenbeck からは, 新 しいことをほとんど学んでいない . 少なくとも私が 評価し得るようなものは $\cdots$ L angenbeck の手術に は本当にうんざりする. 先週も彼の手術で 2 人が死 んだ ...1人はへルニア，もう1人はかわいい健康な 予供で , 彼は上腕骨から小さな骨の突出を切除した のだ」(1852年)

次もこの年の手紙である .

「私は彼(Langenbeck)をどう判断していいか分から ない．ともかく彼は見事な手術をする．私に手術を してほしい人は他にはいない．しかし手術をするか しないかは，彼には決めてほしくない，彼の病理解 剖学の知識は, 新しい方向なのか光れとも時代遅れ なのかよく分からない」(1852年)

このような手紙を読むと，若い Billroth が Langenbeck の手術は science に裏打ちされていない art であ る，と直感的に判断していたように思えてくる．光し て Billroth の教育を受けた者には光れが理解できたか らではないか,だから Langenbeck の門下と言わず,み なBillroth の門下と言うのではないか，と筆者は推測 している。

\section{9 . 先見の明}

Billroth に先見の明があったことは多くの手紙や書 籍，講演からうかがえる。

「患者に手術を恐れさせてはならない．しかし私は， 患者の承諾なしに手術を行うことが正しいとは考え ない」(1866年)

百数十年前にはっきりと「患者の承諾なしに」と言っ ている。

また , 共同研究の重要さについても何回も強調して いる、例えば，

$\ulcorner\cdots$ 樣々の知識をもつ人々がチームとして研究を行 い，乥れ光れの観察結果をお互いに吟味し，結果を 討論することによってのみ, 科学は進歩するのだ， と私は信じている」(1856年)

と, 当時は全く行われていなかった共同研究の必要性 を明示した。

また，ウィーン大学の就任記念講演では，

「…かつてわれわれは外科と内科とが分離している 時代を過ごしてきた．理論と実践，理論外科と実地 外科が壁によって引き離されている時代は終わっ 
た . 現代の純粋科学と応用科学の手法によって, 理 論と実践を別々にする理由はなくなった。諸君はな ぜ,理論が終わって実践に移っている化学者, 物理 学者, 数学者, 技術者と相談しないのか........」(1867 年)

と述べた . 光の他, コメディカルの重要性, 救急患者 の搬送車の考案などもある . また外科医は看護の業務 も含めて，全てを経験すべきだ，とも言っている． 内科医が大胆に外科的処置を行っているし，これか らはもっとひどくなるだろうという指摘もある .

「私の考えでは,心囊液の排液は，一部の外科医が外 科の art の阷落と呼び，他の外科医が軽率としてい るものに極めて近い，…次の世代は異なった判断を するかもしれない．常に内科は，より外科的になっ ていく．内科の専門家は恐れを知らず，外科的処置 をしようとするだろう .この処置が有益であるとい う論拠は, 弚れを除去すれば大量の心囊液によって 室息するのを防ぐか，遅らせることができる，とい うことにある」(1866年)

心囊液の排液については，この時代にレントゲンは じめ診断手段がなく, 腫瘍か, 液体か, 心臓の肥大か を鑑別することができないことから，失敗による危険 があるとして，反対した．また症状の改善も一時的で あることから ,Billroth は無謀だとしている.しかし生 存する者もあると認めているし, 次の時代には変わる かもしれない，とも述べている．

$$
\text { 10.ユーモアと温かい思いやり }
$$

Billroth の書簡を読んでいると，彼のユーモア，ある いは温かい思いやりを感じる．

Billroth は1874年11月にウィーンの A Iser strasse に 家を購入した .かつて A llgemeines Krankenhaus の院 長だった Johann Peter Frank のもので ,この大邸宅で ハイドンやベートーベンも演奏をした .

友人に次のような転宅の通知を書いている．

「私は家を買った .来年破産したら，私の肥満した青 ざめた死体を，君は病院から数軒先の A Iser 街20番 地の家で，見つけることができるだろう」(1874年) 1888年 4 月の手紙に，

「以前は体重が120kg あったのに，今は80kg に減っ てしまった」

とあるので, この頃は確かに肥っていたのであろう .

プラハの外科教授に Heine が選ばれたことを知っ て，候補者の一人だった Czerny に次のような手紙を 書いている.
「物事は弚の流れのままにしておきなさい 君がもて たかもしれない地位について , 幻想を抱いて惨めな 思いをしてはいけない．私にも乥んなことがあった ので，君の状況や気持はよくわかる . 私のウィーン での最初の一年もバラ色というわけではなかった . 君の科学, 君の仕事, 君の家庭に関心を持ちなさい． 物事をもっと気楽に考えなさい. 来るものならきっ とやって来る」(1873年)

ウィーン大学第1外科の Dumreicher の後任とし て, 第 2外科の Billroth は強く門下生のCzerny を推 した.しかし Dumreicher 門下のA Ibert を推す一部の 教授たちによって 最終決定で覆がえされてしまった . 1881年にA Ibert は第1外科の教授に就任した .このこ とから第 1 外科と第 2 外科との間に深い溝ができた .

A Ibert は11年後の1892年に行われた Billroth 開講 25周年講演会に招待された . 大方の予想を裏切って A lbert は关れに応え，祝辞を述べた . 乥して Billroth がZürich を去るときに後任の外科教授の条件として 挙げたものを引用して次のように述べた .

$\ulcorner$ …科学を推進させることが最も期待される外科教 授は, 単に外科臨床だけではなく, 生理学的, 病理 解剖学的研究においても名声を得ていなければなら ない，彼は重要な貢献をする外科医であり，教育者 であり，著作家でなければならないし，しかも若々 しい力に満ちていなければならない. 彼は生理学や 病理解剖学に関連した外科における近年の動向を， 正しく追求しなければならない. 大学の名をあげる 外科教室をつくり，国家に大きな利益をもたらさな ければならない」

A lbert は現在では吻合法に名を残しているが , この A lbert の後任として，第1外科を継いだのが，第 2 外 科の Billroth 門下のE iselsberg である 一方, 第 2 外科 のBillroth の後を継いだのは門下生の Gussenbauer であったが, 弚の後任は第1外科のA lbert 門下の Hochenegg であった こうして両外科の均衡か配慮さ れている.両外科の確執をなくしたのは, 開講25周年 祝賀会への招待と，光れに応えた A lbert の祝辞であ り，光の祝辞の中にあった Billroth の言葉の引用では ないかと推測している。

Billroth は音楽を愛し，オぺラを愛し，作曲も演奏も した .一方，A lbert は詩を愛し，ボへミアの詩をドイ ツ語に訳してBillrothに送っている，光れに応えた Billroth の手紙があり，芸術を愛した 2 人の外科医の 人柄を感じる. 


\section{1 . 理想の教育者}

Billroth の書簡や論文を読むと，Billroth が人々を魅 了する人柄，人々を鼓舞する教育者であったことに気 付く.1876年に刊行されたÜber das Lehren und Lernen der medicinischen Wissenschaften an den Univer sitäten der deutschen Nation に , 理想の教育者 について書かれた一節がある .

「しかし, 輝かしい歴史をもつ医科大学，例えば ウィーン , プラ八 , ヴュルツブルグ ,ゲッチンゲン ベルリン , チュービンゲン , ライプチッヒ大学など を考えるとき，弚れが本当に魅力あるものとしてわ れわれを惹き付けるのは，形式的な一般医学の教育 者ではなく，絶大な力量をもって他のものを鼓舞す る卓越した研究者であることに気付く .このような 力量のある人々がいなくなると，乥れに頼っていた ものは , みなすぐに色あせてしまう」

さらに

「学生がなぜある一人の教師に惹き付けられるのか ということは, 学生にとっては説明がつかないし， 不可解なことであろう．弚れにもかかわらず，彼ら は無意識のうちに教師の考え方，感じ方，行動を真 似る，少なくとも彼らが自分自身の独自のものをも つまでは」

と，教師の影響の大きいことを挙げている．

次も弚の一節である .

「偉大な研究者や医師はいつも何らかの夢をもち 想 像力に富み，常に外へ広がろうという熱望を持って いる. 弚のため，彼らが自分の科学について話しは じめると，学生は奮い立たされたような印象を抱く。 彼らのほとんどは芸術家のような性格をもってい
る．…彼らは若者には抵抗しがたいような魅力，ま るで聖職者のような，あるいは悪霊に取り憑かれた ような魅力をもっている」

ここを読むと，Billrothの言う理想の教育者とは， Billroth 自身ではなかったか，と思えてならない，

Billroth は優れた外科医であり，研究者であった .さ らに关の彼が , 自分のあげた教育者の理想光のもので あったことが , 人々を惹き付け，多くの優れた門下生 を集め，多くの外科学の指導者が育った理由ではない か，と考える.今，Billroth が生きていたとしても，光 のまま現在の外科学の指導者, 研究者, 教育者として 尊敬を集め，多くの外科医を育てていたであろうと確 信している.

$$
\text { 12.おわりに }
$$

Billroth 教授の教育について, 彼の㡲大な書簡や書 籍のうちのごく一部を取り上げ，推察してみた．筆者 の色眼鏡を通してみた Billrothであり，片寄りもあろ う.また，翻訳は全て筆者が行ったので，間違いも多 いかと思う. Billroth についてよくご存知の方も多く おられるので，お教え頂ければ幸いである .

\section{文献}

1) 堺 哲郎: T heodor Billroth の生涯 . 略記 . 外科 $28: 1206-1213,1315-1323,1966,29: 100-109$, 429-439, 1967

2) Mikulicz J : Theodor Billroth. Berliner klinische Wochenschrift $3:$ 199-205, 1894

3) Billroth $T$ : Ü ber das Lehren und Lernen der medicinischen $\mathrm{W}$ issenschaften an den Universitäten der deutschen Nation nebst allgemeinen Bemerkungen über Univer sitäten. Karl Gerold Sons, W ien, 1876

T he T eachings of Prof essor T heodor Billroth

Michio Ogawa

Department of Surgery II, Kumamoto Univer sity Medical School

Many of those serving as assistants to Professor T heodor Billroth went on to become professors of surgery and directors of surgical departments. In this article, the author discusses, based on his letters, articles, and books, how he taught his students to become surgeons and the ty pe of education he thought was ideal. Key words : T heodor Billroth, surgical training, ideal educator

〔Jpn J Gastroenterol Surg 34 : 297-302, 2001〕

Reprint requests : Michio Ogawa Department of Surgery II, Kumamoto U niver sity Medical School 1-1-1 Honjo, Kumamoto, 860-8556 JA PA N 